\title{
Benthic foraminifera distribution in high polluted sediments from Niterói Harbor (Guanabara Bay), Rio de Janeiro, Brazil
}

\author{
CLAUDIA G. VILELA ${ }^{1}$, DANIELE S. BATISTA ${ }^{1}$, JOSÉ A. BAPTISTA-NETO ${ }^{2}$ \\ MIRIAN CRAPEZ ${ }^{3}$ and JOHN J. MCALLISTER ${ }^{4}$ \\ ${ }^{1}$ Departamento de Geologia/IGEO/CCMN - Universidade Federal do Rio de Janeiro, 21949-900 Rio de Janeiro, Brasil \\ ${ }^{2}$ Departamento de Geografia - FFP/UERJ, Departamento de Geologia - Lagemar/UFF 24210-340 Brasil \\ ${ }^{3}$ Laboratório de Microbiologia Marinha - PPGBM/UFF 24001-970 Brasil \\ ${ }^{4}$ School of Geography - The Queen's University of Belfast, BT7 1NN Ireland
}

Manuscript received on July 7, 2003; accepted for publication on October 15, 2003;

presented by Norma Costa CRUZ

\begin{abstract}
Dockyards and harbors are recognized as being important locations where sediment-associated pollutants can accumulate, which constitutes an environmental risk to aquatic life due to potential uptake and accumulation of heavy metals in the biota. The aim of this paper is to assess the concentrations and the effects of some heavy metals in the benthic foraminifera assemblage in Niterói Harbor. Low concentrations in the benthic foraminifera as well as the dominance of indicative species such as Ammonia tepida, Buliminella elegantissima and Bolivina lowmani can be associated with an environment under stress. In addition, the occurrence of test abnormalities among foraminifera may represent a useful biomarker for evaluating long-term environmental impacts in a coastal region.
\end{abstract}

Key words: benthic foraminifera, Guanabara Bay, pollution, heavy-metals.

\section{INTRODUCTION}

Coastal areas, particularly docklands and harbors have been described in the international literature as typical locations where sediment-associated pollutants can accumulate due to anthropogenic activities. Ecological and environmental consequences of contamination produce complex problems and these need to be resolved in order that exposed habitats may be protected. Guanabara Bay, Rio de Janeiro, Southeast Brazil, is considered to be one of the most polluted environments of the Brazilian coastline. Heavy metal contamination accounts for a high percentage of this pollution (Rebello et al. 1986, Van-

Correspondence to: Profa. Dra. Claudia Gutterres Vilela E-mail: vilela@geologia.ufrj.br denberg and Rebello 1986, Leal and Wagener 1993, Baptista Neto et al. 2000). Metal toxicity is complicated when compared to, for example, hydrocarbon pollution since the mode of toxicity in the latter is similar. However, when studying metal pollution, toxicity varies among and within individual elements, depending on their speciation within the sample matrix. Metals are non-bioavailable and can bioaccumulate through various mechanisms (Bruland et al. 1991, Bryan and Langston 1992). It is very important to access their impacts on the microfauna found in the surface sediment.

Benthic foraminifera consist of single cell organisms, some have granular rizopodia and others have elongate filopodia that emerge from the cell body. Benthic foraminifera are present in a wide 
range of marine environments, from brackish estuaries to deep ocean basins at all latitudes. These species are very sensitive to environmental changes and have well defined salinity and temperature preferences, making them very useful indicators of past environmental events (Ellison and Nichols 1976). One method of studying the effects of pollutants is to determine the taxonomic diversity of these organisms by generating diversity index values from mathematical formulas. Diversity is a measure of order (or disorder) within a particular system and by applying the numbers to the Shannon-Wiener equation, as described in Gibson and Buzas (1973), the degree of uncertainty can be determined. Benthic foraminifera have been used as "indicator organisms" to monitor human pollution in coastal regions (Alve 1991, 1995, Yanko et al. 1994, Yanko 1997). Knowledge of the microfaunistic assemblage contributes for the evaluation of the bottom sediments close to highly polluted areas. The response of benthic foraminiferal assemblages to heavy metals and high input of organic matter may be a useful tool when evaluating the impact of these substances in the studied area. Heavy metals and organic matter cause deformities and atrophy in the foraminifera tests, as well as a decrease in diversity and density (Boltovskoy 1956, McCrone and Schafer 1966, Seiglie 1968, Alve 1991, Casamajor and Debenay 1995, Bonetti et al. 1997, Yanko et al. 1998, 1999, Samir 2000). It must be emphasized that heavy metals influence natural bacteria in various ways in that they may enhance, suppress or have no effect on bacterial growth (Ehrlich 1997). Potential toxicity of heavy metals to bacteria depends greatly on factors such as $\mathrm{pH}$, Eh, sulfide, other inorganic elements, organic matter, hydrous metal oxides and clay minerals (Somerfield et al. 1994). Metal speciation and bioavailability are greatly influenced by aerobic and anaerobic conditions. Many metals, for example, $\mathrm{Cu}$ and $\mathrm{Cr}$ exist as dissolved ions under aerobic conditions and as metal-sulfide complexes under anaerobic conditions which reduces their bioavailability (Hare et al. 1994).

\section{MATERIALS AND METHODS}

Fifteen samples were collected in June 2000, using a Van-Veen Grab sampler, from Guanabara Bay, Niterói, R.J. Brazil, located between $22^{\circ} 70^{\prime}$ to $23^{\circ} 00^{\prime} \mathrm{S}$ and $043^{\circ} 00^{\prime}$ and $043^{\circ} 30^{\prime} \mathrm{W}$ (Figure 1). The study area includes the Niterói Harbor, Conceição Island and the Jurujuba Sound. This municipality is marked by intensive naval activities and holds one of the main naval estates in the country.

Samples were stored in sealed polythene bags, transported to the laboratory, air-dried at $30-35^{\circ} \mathrm{C}$ in a fan-assisted oven, and separated into three subsamples. Each sediment sample was separated immediately after collection $(80 \mathrm{ml})$ for foraminifera analyses, stored in polythene flasks and stained with Rose Bengal. In the laboratory samples were washed and sieved through 0.062 and $0.50-\mathrm{mm}$-mesh sieves and oven dried at $50^{\circ} \mathrm{C}$. The $0.062 \mathrm{~mm}$ fractions were examined under a binocular microscope and a minimum count of 100 specimens of benthic foraminifera for each sample was observed, following the usual methodology for confined or stressed environments. Where necessary, samples were previously divided according to the methodology described by Boltovskoy and Wright (1976). Standard microscope studies and the use of a Scanning Electron Microscopic Zeiss - DSM 940A were carried out to identify the most significant specimens, normal or deformed. Benthic foraminifera were classified at species level and quantitative analyses included relative and total abundances, diversity and deformity of tests. The live and dead specimens were estimated by counting the stained and unstained specimens immediately after collection.

Samples for chemical analyses were oven dried at $105^{\circ} \mathrm{C}$ and the $<63 \mu \mathrm{m}$ fractions separated by passing them through a nylon mesh sieve. Subsamples $(0.1 \mathrm{~g})$ of these fractions were digested in $5 \mathrm{ml}$ of an aqua regia solution under pressure in PTFE digestion bombs. Oxidizable organic carbon was determined using the Walkley and Black (1934) technique and particle size analysis used a combination of wet sieving $(2 \mathrm{~mm}-63 \mu \mathrm{m})$ and pipette anal- 


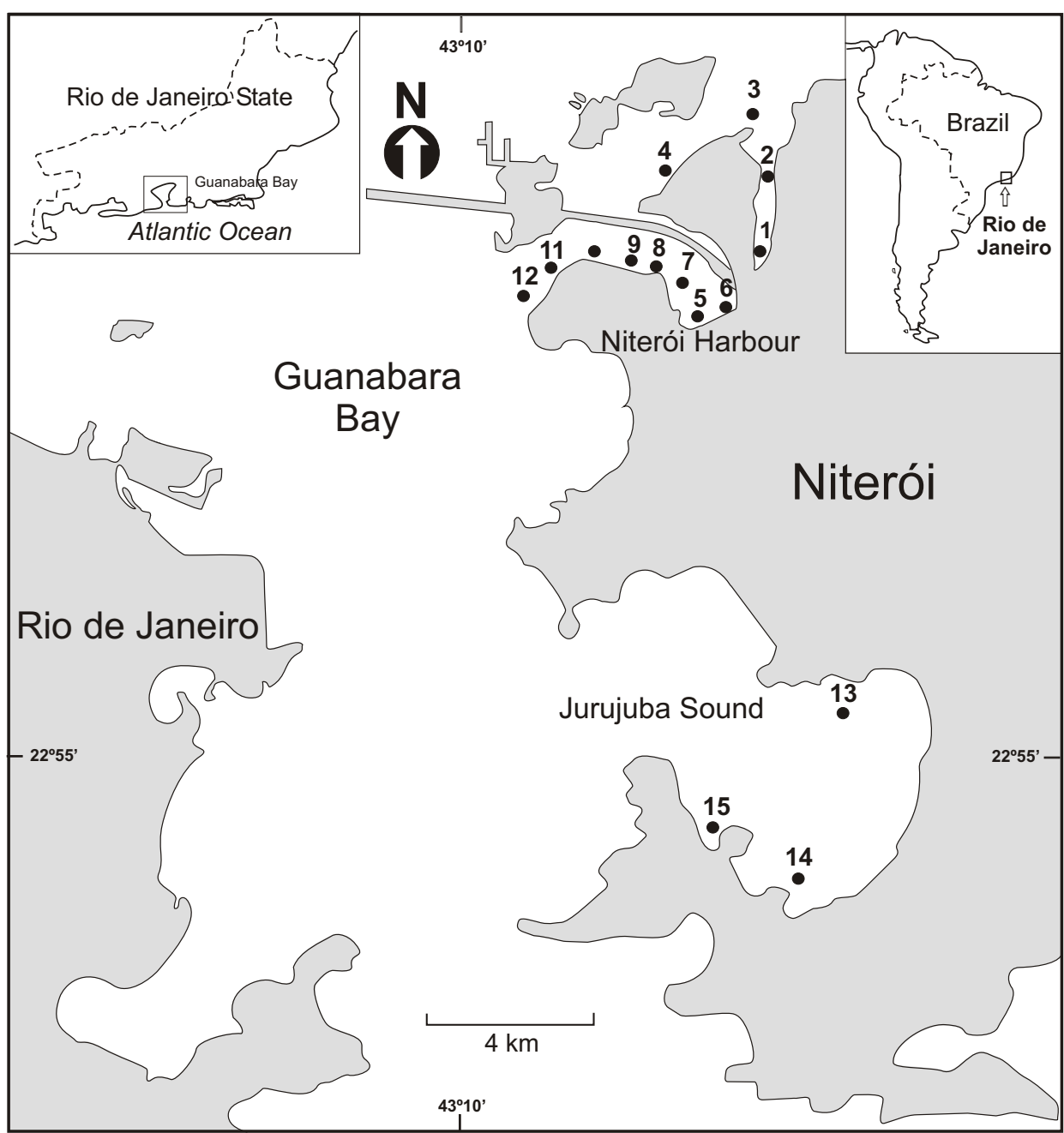

Fig. 1 - Location of the study area and sample stations collected in Niterói, Guanabara Bay, in June 2000.

ysis $(<63 \mu \mathrm{m})$ techniques (Van Doesburg 1996). Elemental analysis was carried out using a Perkin Elmer Model 3100 atomic absorption spectrophotometer.

\section{RESULTS}

\section{PARTicle Size}

In coastal bays, sediments form a textural continuum ranging from a sand-silt-clay mix on one side to well-sorted sand on the other, which represents the final product from the reworking of the sediments by wave and tidal action. The wave and tidal cur- rents lose energy in the inner part of the bay and when human influences become important in the catchments, the sediment pattern and rate of sedimentation can be completely disturbed. According to Amador (1997), poor sediment sorting is related to the superposition of different sediment sources and the low energy of the tidal current circulation is due to the restricted nature of the area. A large number of particle size classes were also observed in the study area and this would indicate very poor sediment sorting. This behavior is also associated with the proximity and superposition of different sediment sources and with the influence of anthro- 
pogenic sediments derived from the industrial and naval activities (Figure 2).

\section{Geochemistry of the Sediments}

Heavy metal distribution in the marine sediments is influenced by texture, clay-minerals, organic matter, oxides, oxyhydroxides of iron and manganese and calcium carbonate (Salomons and Förstner 1984). Harbors, marinas and dockyards are normally restricted areas and consequently have a low circulation of sediment, which makes them preferential sites for the deposition of pollution. Table I shows the concentration values for $\mathrm{Cu}, \mathrm{Pb}, \mathrm{Zn}, \mathrm{Ni}$ and $\mathrm{Cr}$ in surface sediments from Niterói coast, where $\mathrm{Zn}, \mathrm{Cr}$ and $\mathrm{Ni}$ show similar patterns. Higher concentrations were found in sample 6, which is located close to the dockyard and ship painting activities that are carried out in the harbor. These elements have also been found in the paints used by the naval industry (Bellinger and Benham 1978). Table I shows higher metal concentrations in samples located close to Niterói harbor and the dockyard than for those recorded in the international literature from other harbor locations (Förstner and Wittmann 1983, Smith and Orford 1989, Subramanian et al. 1988).

\section{Benthic Foraminifera AnALyses}

Results showed microfauna to be of low abundance, with many small and abraded tests, and some of them deformed. Table I presents absolute values of abundance for the total fauna, stained specimens (alive immediately after collection) and deformed tests. The less abundant samples were located in Niterói Harbor, (Samples 5, 6 and 7 respectively). Sample 11, located close to the main channel of Guanabara Bay was the most abundant and contained many stained but no deformed specimens.

The Shannon-Wiener $(\mathrm{H})$ function was used to estimate the species diversity in each sample, given by the formula:

$$
\mathrm{H}(\mathrm{S})=-\Sigma \text { pi ln pi, where }
$$

S: number of species

pi: proportion of species in the sample

The diversity values (Table I) can be considered low, compared with values for continental shelves (Sen Gupta and Kilbourne 1974, Gibson and Buzas 1973). Comparing these data with the pattern of diversity from other areas in Guanabara Bay, they are similar to data found in other restricted regions, such as the north of the Bay (Vilela et al. 2002), which is considered one of the most polluted areas, close to the main oil refineries in Rio de Janeiro (Rebello et al. 1986, Vandenberg and Rebello 1986, Leal and Wagener 1993).

Quantification of the total fauna (alive and dead) as well as their abundance, diversity and dominance trends was carried out. The abundance patterns related below were used for about 100 specimens or splitter fraction, using a volume of $80 \mathrm{ml}$ of total sample: simple -1 ; rare -2 to 3 ; common -4 to 6 ; frequent -7 to 12 ; abundant -13 or above. Dominance is the tendency of one species to represent a great part of the assemblage, defined by the occurrence of the species in that assemblage (Boltovskoy and Totah 1985). Frequent or abundant species present in all samples were considered dominant (Figure 3).

\section{DISCUSSION}

Figure 4 illustrates the main benthic foraminifera species present in Niterói samples. Occurrence of the dominant species Buliminella elegantissima, Ammonia tepida and Bolivina lowmani in the samples is shown in Figure 5. These species are commonly encountered in restricted environments under pollution stress (Yanko et al. 1994, 1999, Alve 1995, Culver and Buzas 1995, Sousa et al. 1997, Bonetti et al. 1997, Debenay et al. 2000, Van der Zwann 2000). While B. elegantissima dominated in all the samples, $A$. beccarii and species like Elphidium discoidale and Textularia earlandi were abundant in samples located outside the harbor. These observations are significant since it is possible to correlate 


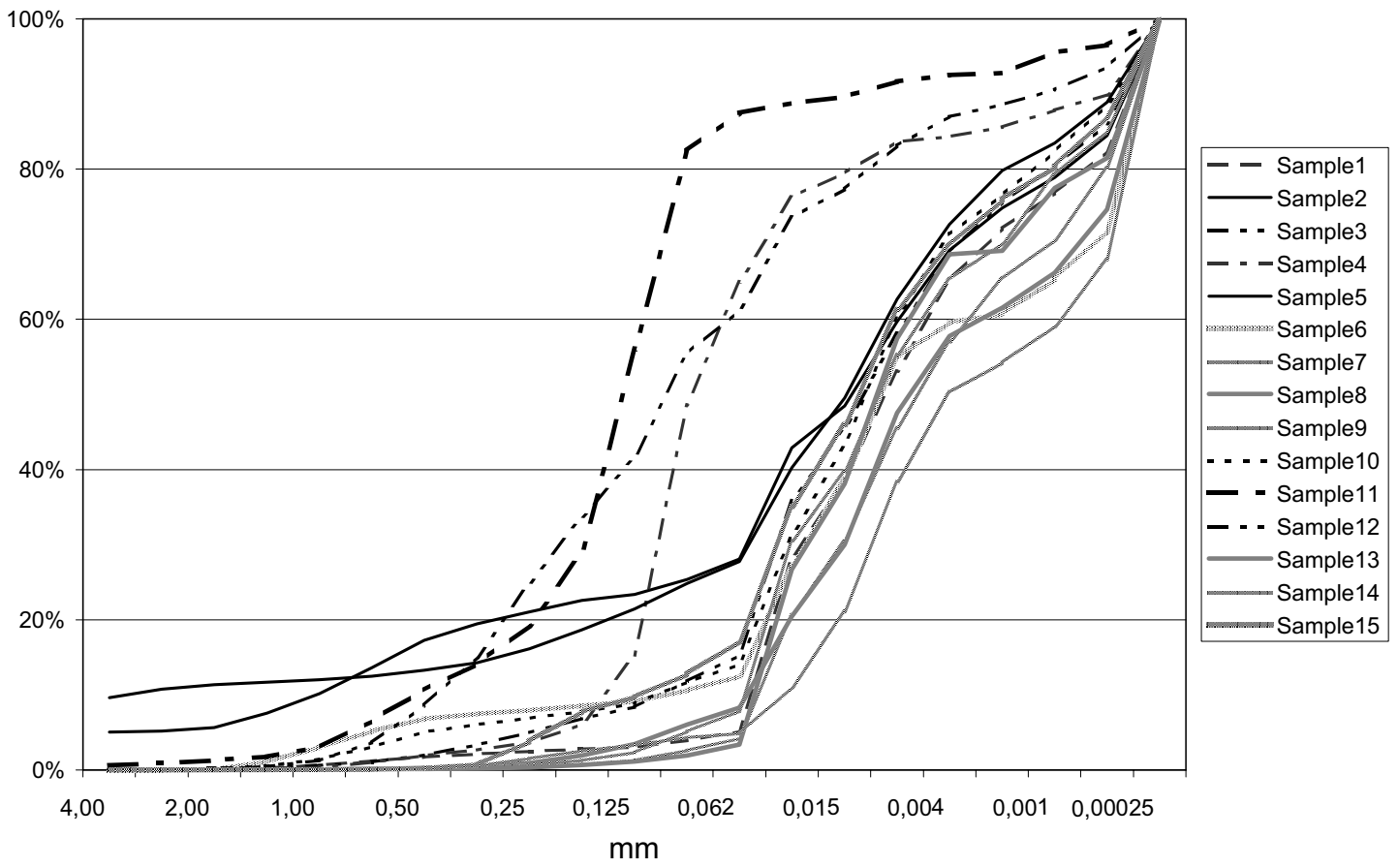

Fig. 2 - Particle size of the bottom sediments from Niterói, Guanabara Bay.

\section{TABLE I}

Total abundance of benthic foraminifera per sample, stained and deformed specimens, Shannon-Wiener H(S) diversity, and heavy metal results (ppm).

\begin{tabular}{c|c|c|c|c|c|c|c|c|c}
\hline Samples & Tot. abund. & Stained & Deform. & $\mathrm{H}(\mathrm{S})$ & $\mathrm{Ni}$ & $\mathrm{Pb}$ & $\mathrm{Cu}$ & $\mathrm{Zn}$ & $\mathrm{Cr}$ \\
\hline 1 & 1304 & - & - & 2,51 & 80 & 110 & 125 & 360 & 105 \\
2 & 3584 & 7 & - & 2,51 & 60 & 45 & 35 & 115 & 85 \\
3 & 7360 & - & - & 2,46 & 70 & 70 & 75 & 205 & 105 \\
4 & 4224 & 6 & - & 2,49 & 70 & 70 & 340 & 310 & 160 \\
5 & 460 & - & 1 & 2,63 & 90 & 120 & 155 & 325 & 105 \\
6 & 720 & 3 & 2 & 2,54 & 110 & 115 & 1450 & 850 & 230 \\
7 & 466 & 9 & 6 & 2,93 & 50 & 95 & 105 & 270 & 100 \\
8 & 4288 & 2 & 3 & 2,83 & 60 & 135 & 155 & 370 & 120 \\
9 & 11936 & 10 & - & 2,79 & 60 & 80 & 105 & 220 & 95 \\
10 & 7936 & 5 & - & 2,59 & 60 & 115 & 125 & 225 & 135 \\
11 & 62720 & 18 & - & 2,99 & 60 & 90 & 350 & 385 & 95 \\
12 & 1952 & 31 & 3 & 3,61 & 80 & 55 & 415 & 320 & 165 \\
13 & 7200 & 16 & 11 & 2,38 & 30 & 45 & 45 & 160 & 75 \\
14 & 2584 & 35 & - & 2,21 & 30 & 50 & 55 & 170 & 85 \\
15 & 23296 & 2 & 1 & 2,61 & 30 & 70 & 75 & 205 & 80 \\
\hline
\end{tabular}



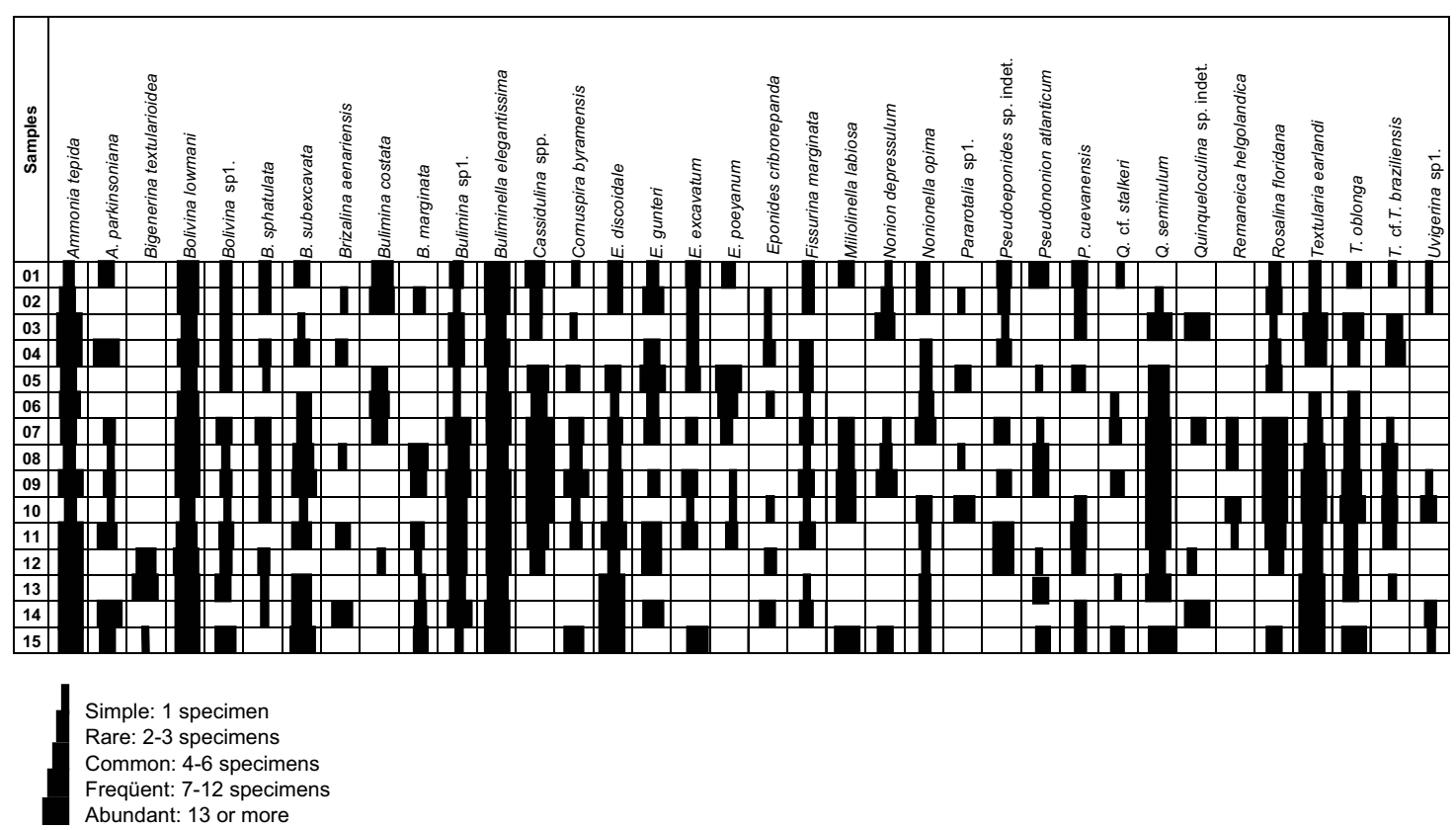

Fig. 3 - Benthic foraminifera relative abundance in samples from Niterói, Guanabara Bay. Species with Rare occurrence in 3 samples or less were not considered.

the occurrence of B. elegantissima to the most restricted and polluted studied areas.

Stained specimens were scattered and more numerous among the dominant species such as $B$. elegantissima, A. tepida and B. lowmani, in samples located near the main channel of the bay and in Jurujuba Sound (Table I; Figure 6). Various types of deformities were observed in a few tests and these were mainly in B. lowmani and A. tepida, recovered from samples collected close to the harbor and inside Jurujuba Sound (Table I; Figure 6). Morphological variations in the benthic foraminifera tests have been related to a combination of several parameters: temperature, salinity, carbonate solubility, depth, nutrients, bottom type, oxygen dissolution, lighting, pollution, currents, trace elements and rapid changes in the environment (Boltovskoy et al. 1991). A. tepida can live in restricted environments under stress, and can acquire deformities due to various reasons, one of these being the presence of heavy metals (Yanko et al. 1998, Samir 2000, Sharifi et al. 1991). Several authors have concluded that the evaluation of defor- mities in the foraminifera tests could be used as a bioindicator of heavy metal pollution (Alve 1991, Yanko et al. 1994, 1998, Geslin et al. 1998).

The predicted results would be a higher number of deformities close to the harbor and around Ilha da Conceição due to the stress conditions caused by increased pollution in these areas. These conditions are due to the location of the main dockyard activities and ship movements in the harbor, which increase the level of heavy metals deposited from ship paint and fuel. Deformities were observed mainly in the harbor samples, where one of the main sewage outflows for the city is located and in one sample (13), located north of Jurujuba Sound close to a sewage outflow and also close to a marina. High concentrations of heavy metals have been recorded for sediments inside Jurujuba Sound and results showed this area to be one of the most polluted in Guanabara Bay (Baptista Neto et al. 2000). Results from this study would indicate that the deformities are related to the high levels of heavy metals and organic matter. On the other hand, lower values 


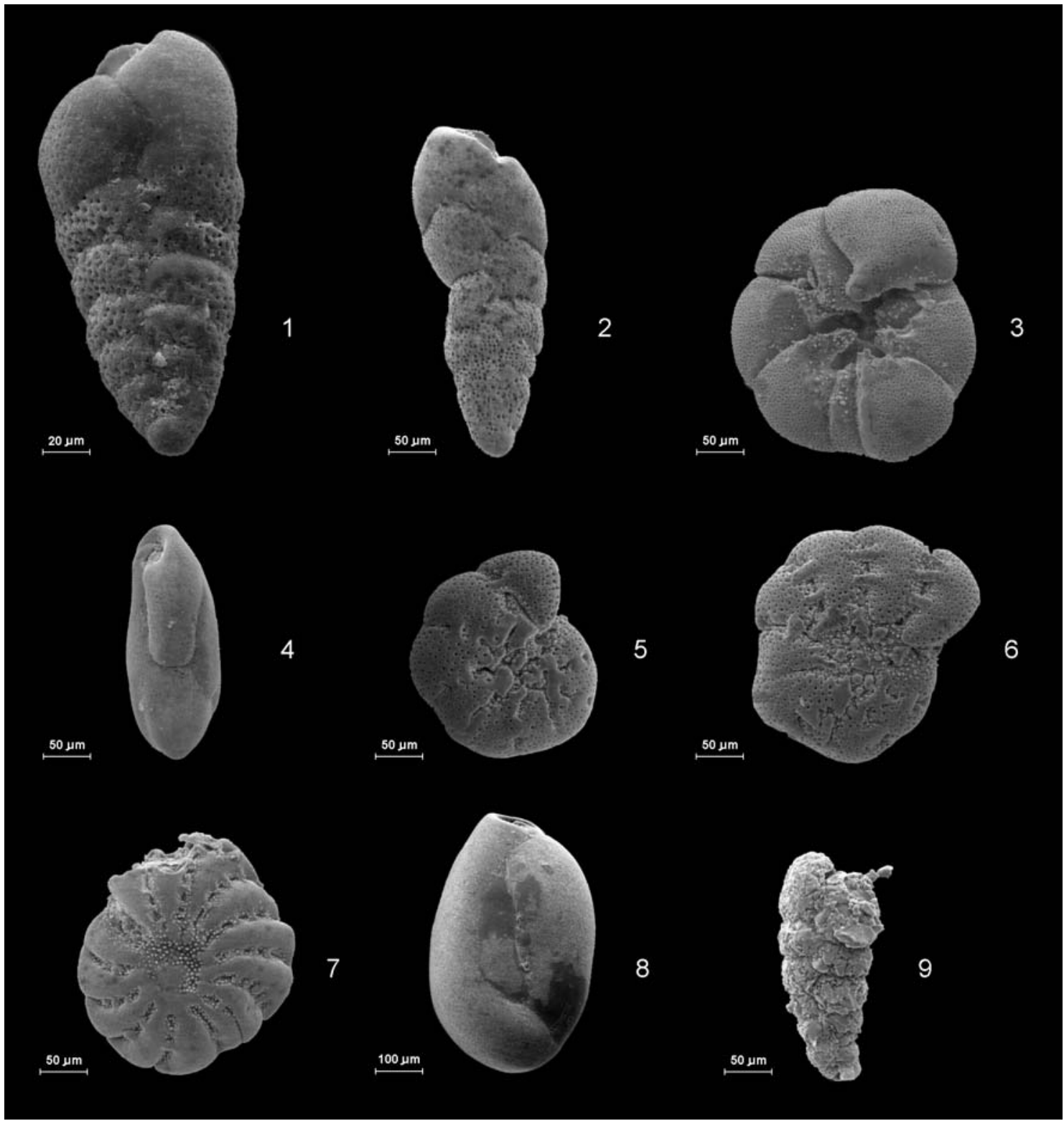

Fig. 4 - SEM photomicrographs of specimens from Niterói, Guanabara Bay: (1) Bolivina lowmani - Sample 15, collected in June 2000; (2) B. lowmani, deformed - Sample 14, collected in June 2000; (3) Ammonia tepida (Cushman) - Sample 40, collected in November 1999; (4) Buliminella elegantíssima (Orbigny) - Sample 15, collected in June 2000; (5) Elphidium gunteri Cole - Sample 14, collected in June 2000; (6) E. gunteri, deformed - Sample 14, collected in June 2000; (7) E. discoidale (Orbigny), deformed and broken - Sample 15, collected in June 2000; (8) Quinqueloculina seminulum (Linné) - Sample 14, collected in June 2000; (9) Textularia earlandi (Parker), broken - Sample 60, collected in November 1999. 


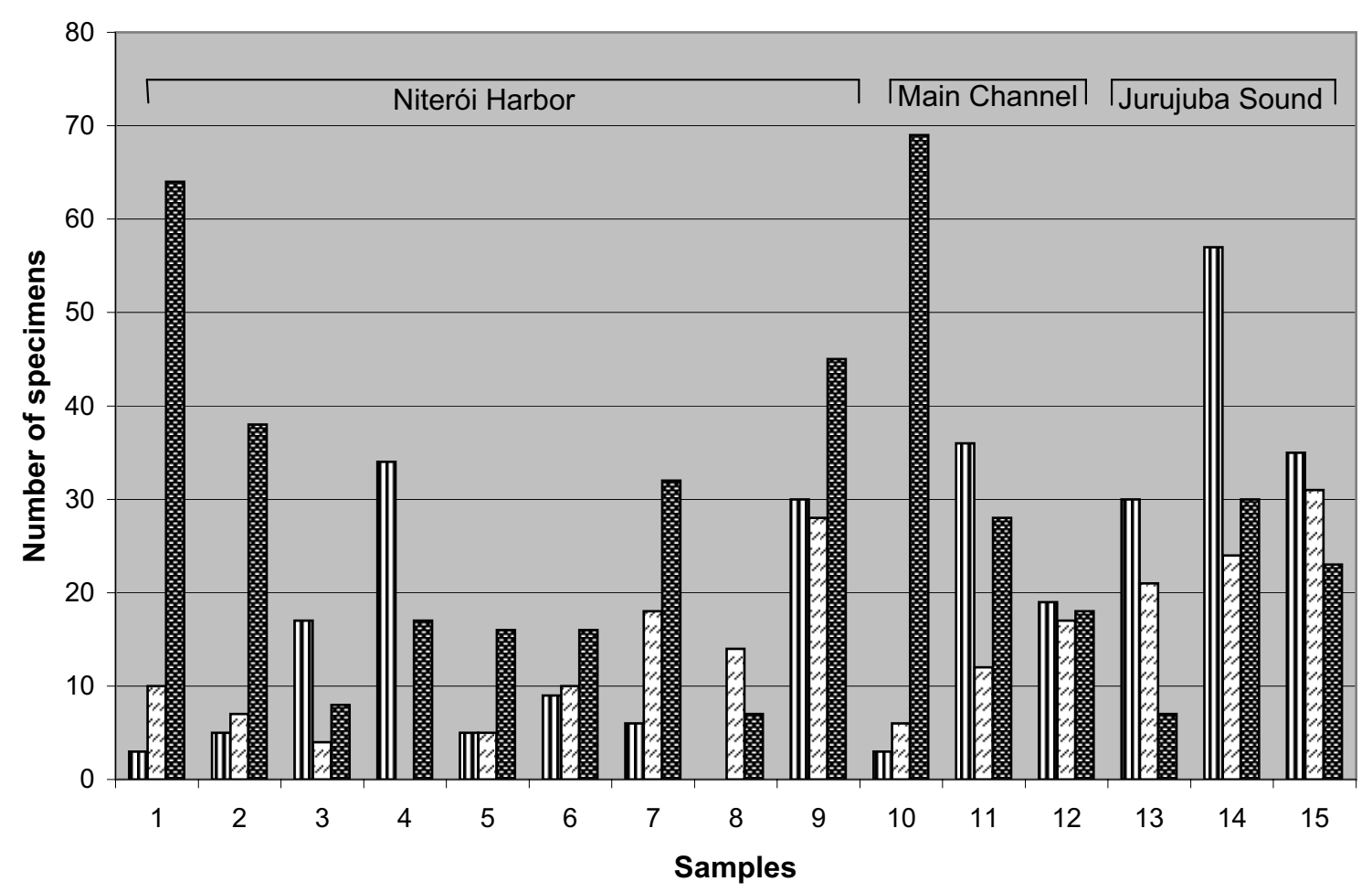

m Ammonia tepida

Bolivina lowmani

Buliminella elegantissima

Fig. 5 - Benthic foraminifera relative abundance (for 100 specimens) of the dominant species in samples from Niterói, Guanabara Bay.

of abundance were found at samples 5, 6 and 7, in Niterói Harbor, which contain the highest levels of heavy metals (Table I).

Microfauna results when compared with other regions inside the bay indicated a very restricted and confined environment under high pollution stress. These results correlate with those from other areas that are also under environmental stress, such as the Rio de Janeiro Harbor and the northern area of the Bay (Vilela et al. 2002).

\section{CONCLUSIONS}

The benthic foraminifera assemblage found in the study area is poor and is represented mainly by small specimens with weak and fragile tests. This is characteristic of a restricted or confined environment under stress caused by high levels of industrial and domestic pollution. High levels of heavy metals and organic matter are present in this area due to the restricted geographical location and intense anthropogenic activities which includes one of the main naval bases in southwest Brazil. The levels of heavy metals in this area are higher than those found in samples from the natural background and it is comparable with the highest polluted coastal environments from other parts of the world. The low values of abundance as well as the dominance of indicative opportunistic species, such as Ammonia tepida, Buliminella elegantissima and Bolivina lowmani, are results of these polluted conditions. The distribution patterns of these benthic foraminifera species in a polluted marine environment demonstrated them to be very sensitive and inexpensive biomarkers capable of indicating deterioration of shallow marine environments, especially those associated with heavy metal pollution, in the Guanabara Bay. 


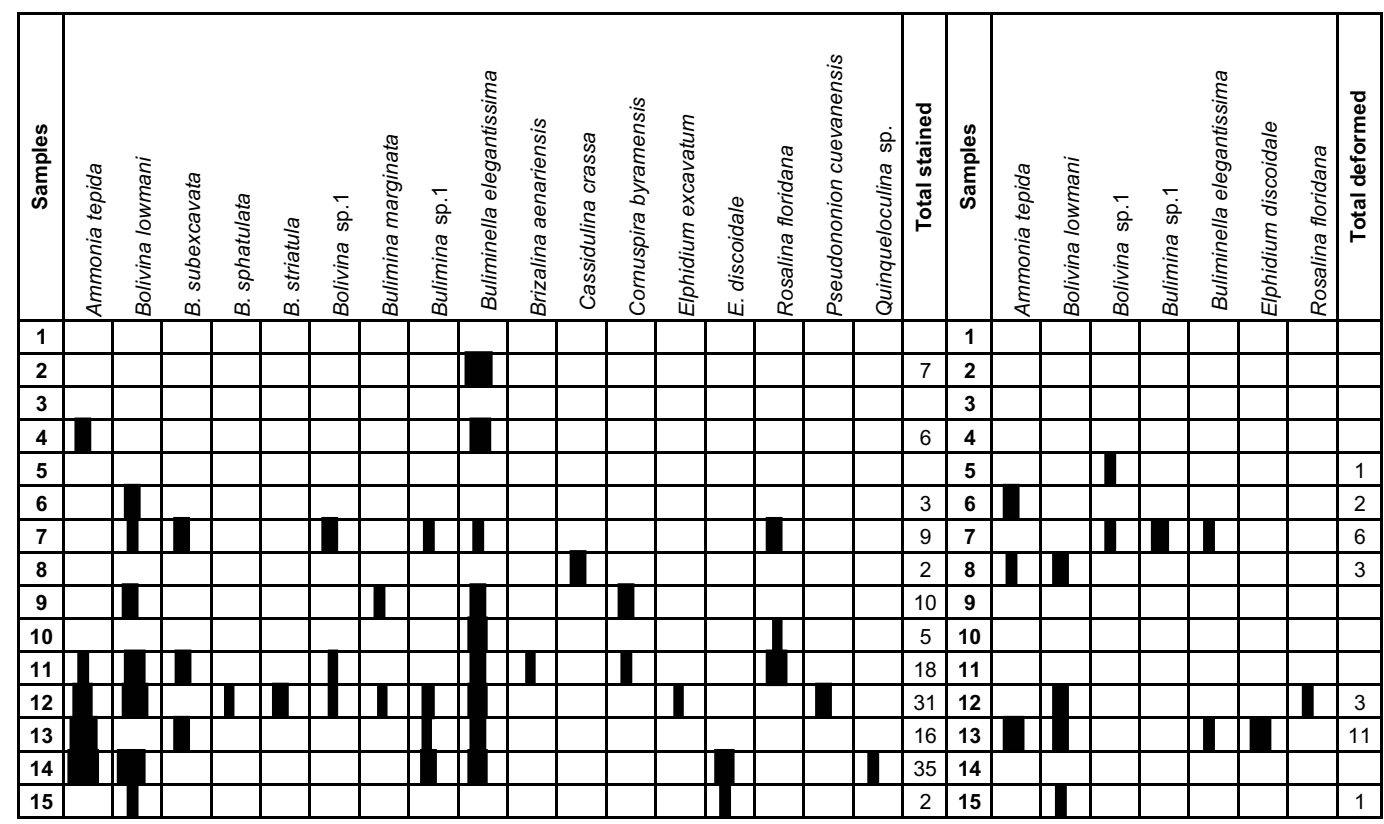

Simple: 1 specimen

Rare: 2-3 specimens

Common: 4-6 specimens

Freqüent: $7-12$ specimens

Abundant: 13 or more

Fig. 6 - Frequence of stained and deformed foraminiferal tests in samples from Niterói, Guanabara Bay.

\section{ACKNOWLEDGMENTS}

This research was supported by FAPERJ (Rio de Janeiro State Science Foundation), the Department of Geology from Universidade Federal do Rio de Janeiro, Departments of Geology and Biology from Universidade Federal Fluminense/Niterói, Department of Geography/FFP from Universidade do Estado do Rio de Janeiro, and The School of Geography from Queen's University of Belfast/UK.

Thanks are given to Dr. Norma Maria da Costa Cruz, from CPRM (Mineral Resources Company), and the anonymous reviewers of the manuscript.

\section{RESUMO}

Estaleiros e portos são locais reconhecidamente importantes onde poluentes associados a sedimentos podem acumular, constituindo um risco ambiental para a vida aquática devido ao potencial de captação e acumulação de metais pesados na biota. O propósito deste trabalho é avaliar as concentrações e os efeitos de alguns metais pesados na assembléia de foraminíferos bentônicos no Porto de Niterói. Baixas concentrações de foraminíferos bentônicos bem como a dominância de espécies indicativas como Ammonia tepida, Buliminella elegantissima e Bolivina lowmani podem ser associadas a um ambiente sob estresse. A ocorrência de anormalidades entre os foraminíferos pode representar um útil biomarcador para avaliação de impactos ambientais de longo termo em uma região costeira.

Palavras-chave: foraminíferos bentônicos, Baía de Guanabara, poluição, metais pesados.

\section{REFERENCES}

Alve E. 1991. Benthic foraminifera in sediment cores reflecting heavy metal pollution in Sorfjord, Western Norway. J For Res 21: 1-19.

Alve E. 1995. Benthic foraminiferal responses to estuarine pollution: a review. J For Res 25: 190-203. 
Amador ES. 1997. Baia de Guanabara e ecossistemas periféricos - Homem e Natureza. Rio de Janeiro, Reproarte Gráfica e Editora, 529 p.

Baptista Neto JA, Smith BJ and MCAlister JJ. 2000. Heavy metal concentrations in surface sediments in a nearshore environment, Jurujuba Sound, SE Brazil. Envir Poll 109: 1-9.

Bellinger EG And Benham BR. 1978. The levels of metals in dockyard sediments with particular reference to the contributions from ship-bottom paints. Envir Poll 15: 71-81.

Boltovskoy E. 1956. Applications of chemical ecology in the study of foraminifera. Micropaleontology 2: 321-325.

Boltovskoy E and Totah V. 1985. Diversity, similarity and dominance in benthic foraminiferal fauna along one transect of the Argentine shelf. Rev Micropaleont 28: 23-31.

Boltovskoy E and Wright R. 1976. Recent Foraminifera. Dr. W. Junk Publs, The Hague, 515p.

Boltovskoy E, Scott DB And Medioli FS. 1991. Morphological variations of benthic foraminiferal tests in response to changes in ecological parameters: a review. J Paleont 65: 175-185.

Bonetti C, Debenay JP and Eichler BB. 1997. Deformation in benthic foraminifer tests from a polluted Brazilian coastal system. In: The First InTERNAtional Conference Application of Micropaleontology in Environmental Sciences, Tel Aviv. Program \& Abstracts, Herzlia: Anamet Ltd., 1997, p. 41-42.

Bruland KW, Donat J and Hutchins DA. 1991. Interactive influences of bioactive trace metals on biological production in oceanic waters. Limnol Oceanogr 36: $1555-1577$.

Bryan GW AND LANGSTON WJ. 1992. Bioavailability, accumulatin and effects of heavy metals in sediments with special reference to United Kingdom estuaries: a review. Environ Poll 76: 89-131.

Casamajor MN and Debenay JP. 1995. Les Foraminifères, bio-indicateurs des environnements paraliques: réaction à divers types de pollution dans l'estuaire de l'Adour. In: ANPP COLlOQue InTERnACIONAL: Marqueurs Biologiques de Pollution, Chinon, 1995, p. 371-378.
Culver SJ and Buzas MA. 1995. The effects of anthropogenic habitat disturbance, habitat destruction, and global warming on shallow marine benthic foraminifera. J For Res 25: 204-211.

Debenay JP, Guillou JJ, Redois F and Geslin E. 2000. Distribution trends of foraminiferal assemblages in paralic environments: a base for using foraminifera as bioindicators. In: MARTIN RE (Ed.), Environmental Micropaleontology, Topics in Geobiology 15, New York: Kluwer Acad. \& Plenum Publ., p. 39-67.

EHRLICH HL. 1997. Microbes and metals. Appl Microbiol Biotechnol 48: 687-692.

Ellison RL AND Nichols MM. 1976. Modern and Holocene foraminifera in the Chesapeake Bay region. In: Schafer CT and Pelletier BR (Eds.) First international symposium on benthic foraminifera of the continental margins, Part A: Ecol Biol Mar Sed Sp Publ, 1976, p. 131-151.

Förstner U ANd Wittmann GTW. 1983. Metal pollution in the aquatic Environment, Heidelberg: Springer, $486 \mathrm{p}$.

Geslin E, Debenay JP and Lesourd M. 1998. Abnormal wall textures and test deformations in Ammonia (hyaline foraminifer). J For Res 28: 148-156.

Gibson TG and Buzas MA. 1973. Species Diversity: Pattern in modern and Miocene foraminifera of the eastern margin of North America. Geol Soc Amer Bull 84: 217-238.

Hare L, Carignan R and Huerta-Diaz MA. 1994. A field study of toxicity and accumulation by benthic invertebrates, implications of the acid-volatile sulphide (AVS) model. Limnol Oceanogr 39: 1653-1668.

Leal M And Wagener A. 1993. Remobilization of anthropogenic copper deposited in sediments of a tropical estuary. Chem Spec Bioav 24: 31-39.

McCrone AW and Schafer CT. 1966. Geochemical and sedimentary environments of foraminifera in the Hudson River estuary, New York. Micropaleontology 12: 505-509.

Rebello A, Haekel W, Moreira I, Santelli R and Schroeder F. 1986. The fate of heavy metals in an estuarine tropical system. Mar Chem 18: 215-225.

Salomons W and Förstner U. 1984. Metals in the Hydrocycle, Berlin: Springer-Verlag, 349 p. 
SAMIR AM. 2000. The response of benthic foraminifera and ostracods to various pollution sources: a study from two lagoons in Egypt. J For Res 30: 83-98.

SEIGLIE GA. 1968. Foraminiferal assemblages as indicators of high organic carbon contents in sediments and of polluted waters. AAPG Bull 52: 2231-2241.

Sen Gupta BK and Kilbourne RT. 1974. Diversity of benthic foraminifera on the Georgia continental shelf. Geol Soc Amer Bull 85: 969-972.

Sharifi AR, Croudace IW and Austin RL. 1991. Benthic foraminiferids as pollution indicators in Southampton Water, southern England, UK. J Micropal 10: 109-113.

Smith BJ AND ORFord JD. 1989. Scales of pollution in estuarine sediment around the North Irish Sea. In: SweEney, JC (Ed.) The Irish Sea, a resource at risk: Geogr Soc Irel Spec Publ 3, p. 107-116.

Somerfield PJ, Gee JM And Warwick RM. 1994. Soft sediment meiofaunal community structure in relation to a long-term heavy metal gradient in the Fal Estuary system. Mar Ecol Prog Ser 105: 79-88.

Sousa SHM, Duleba W, Kfouri P, Eichler BB and FurTAdO VV. 1997. Response of foraminiferal assemblages to environmental changes in the São Sebastião Channel, northern coast of São Paulo State, Brazil. In: The First International ConferEnCE Application of Micropaleontology in ENvironmental Sciences, Tel Aviv. Program \& Abstracts, Herzlia: Anamet Ltd., 1997, p. 109-110.

Subramanian V, ItTA PK AND Griekan RV. 1988. Heavy metals in the Ganges Estuary. Mar Poll Bull 19: 289-293.

Vandenberg C ANd Rebello AL. 1986. Organiccopper interactions in Guanabara Bay, Brazil - an electrochemical study of copper complexation by dissolved organic material in a tropical bay. The Sci Total Envir 58: 37-45.
VAN DER ZWANN GJ. 2000. Variation in natural vs. anthropogenic eutrophication of shelf areas in front of major rivers. In: MARTIN RE (Ed.), Environmental Micropaleontology, Topics in Geobiology 15, New York: Kluwer Acad. \& Plenum Publ., p. 385-404.

Van Doesburg JDJ. 1996. Particle size analysis and mineralogical analysis. In: BuURMAN P ET AL. (Eds.), Manual for Soil and Water Analysis, Leiden: Backhuys Publ., p. 251-267.

Vilela CG, Baptista Neto JA, Mendonça Filho JG, SANJinés AES, Batista DS ANd Barbosa CF. 2002. Benthic foraminifera occurrence in subenvironments on Guanabara Bay, Rio de Janeiro, southeast Brasil. In: FORAMS 2002 INTERNATIONAL SyMPOSIUM ON Foraminifera, Perth. Vol. Abstr., Perth, 2002, p. 70.

WalkLey A AND Black IA. 1934. An examination of the Degtjareff method for determing soil organic matter and proposed modification of the chronic acid titration method. Soil Sci 37: 29-38.

YANко V. 1997. Benthic foraminifera as bioindicators of stress environment: anthropogenic problems - foraminiferal solution. In: THE FIRST INTERNAtional Conference Application of MicropaleOntology in Environmental Sciences, Tel Aviv. Program \& Abstracts, Herzlia: Anamet Ltd., 1997, p. $117-119$

Yanko V, Kronfeld J and Flexer A. 1994. Response of benthic foraminifera to various pollution sources: implications for pollution monitoring. J For Res 24: $1-17$.

Yanko V, Ahmad M and Kaminsky M. 1998. Morphological deformities of benthic foraminiferal tests in response to pollution by heavy metals: implications for pollution monitoring. J For Res 28: 177-200.

YANKo V, ARnOLd AJ AND PARKer WC. 1999. Effects of marine pollution on benthic Foraminifera. In: SEN GuPTA BK (Ed.), Modern Foraminifera, New York: Kluwer Acad. Publ., p. 217-235. 